\title{
Nuclear Concern
}

\author{
Adriianne Foss* \\ Grant MacEwan University, Canada
}

\begin{abstract}
Finding an alternative energy source to fossil fuels is becoming increasingly important. This has led many countries to question whether nuclear power, touted as an environmentally friendly source of energy, is the answer. A look at the environmental effects attached to this source of energy - the risk of radiation exposure for communities adjacent to nuclear plants, and nuclear power's volatile history-coupled with current events provides countries with reason to seriously doubt the safety and sustainability of this energy source. Nuclear plants do immediate damage to the system in which they are built, and that is not the end of their effects. Continuous release of radiological material into the surrounding area that threatens the ecology and nearby communities, the creation of waste, for which there is currently no solution, and a threat of radioactive materials falling into the hands of terrorist activists also weigh heavily against the sustainability of this energy source. The history of the nuclear industry makes it undeniable that more nuclear disasters are inevitable. Every community is vulnerable, whether a nuclear disaster is caused by nature's wrath, as in Japan, or by human or technological error, as in many previous nuclear accidents, including Chernobyl. The countries of the world have a weighty decision to make about whether nuclear energy is the answer.
\end{abstract}

Nuclear energy is touted as a clean, efficient, and inexpensive source of energy, but is it safe? Recently, the world watched as a nuclear catastrophe unfolded in Japan. The long term effects of this ongoing tragedy are unknown as of yet, but "government officials warned Friday that there were no plans to lift the evacuation order anytime soon" (Alibaster \& Yamaguchi, 2011, para. 13). With such potential for catastrophe, it is 
important to consider the facts about nuclear power before adopting it entirely to fuel our lifestyles and our economies. The negative consequences greatly outweigh the benefits, and considering nuclear power's history, additional disasters seem inevitable.

Paschoa (2004) recognizes that nuclear energy, the energy released from the nucleus of an atom through sustained fission, has been tamed since its use during World War II in the development of military weapons (p. 4, para. 2). Since then, nuclear energy has been "used commercially . . . to meet a fraction of the electrical energy needs" (ElHinnawi, 1976, para. 1). It is considered a green energy source.

Negative environmental effects contradict this. Paschoa (2004) notes a nuclear plant begins disturbing the environment at inception. Trees are cleared, land is excavated, and new roads are built, demolishing animal food sources and natural habitats. Large manmade lakes replace natural rivers, in the case of a hydroelectric plant (p. 6). Furthermore, nuclear reactors routinely release radioactive material into the air and nearby water sources during normal operation (Caldicott, 2006, p.48). In previous "examinations of the impact of energy on the environment, it has become apparent that individual nations are not isolated ... the actions of one country may well result in environmental damage in a neighbouring State" (El-Hinnawi, 1976, para. 4). This is evident as western North America is exposed to effects of a crisis an ocean away. "The Environmental Protection Agency and the Food and Drug Administration in the U.S. state that very low levels of radiation have been detected in a sample of milk from Washington" (Ramu, 2011, para. 1). Advocates of nuclear energy argue that it expels less carbon dioxide, a heavy pollutant, into the atmosphere in comparison to fossil fuels. According to the World Nuclear Association (WNA), in 2011 "Nuclear power reactors operating in 32 countries . .. provide fourteen percent of the global electricity" (para. 2). Dutch researchers "found that nuclear power plants that use high-grade ore . . . emit about 40 percent of the greenhouse gas emissions of a natural gas power plant, from ore refining and plant construction" (Hunt \& Krieger, 2006, para. 6). Andseta, et al. (1998) noted in their research that greenhouse gas emissions from nuclear plants rise as more fossil energy is needed to refine lower quality ore (Review, para. 2).

Nuclear power is not the only alternative to fossil fuels. Many power companies are beginning to adopt green energy sources that do not have the same risks as those associated with nuclear power. One such source is tidal power, which is "as reliable as the orbit of the moon" (Blue Energy, 2009, para. 1) according to Blue Energy, a company committed to finding alternate energy. Solar energy is used successfully around the world including Israel, which, according to Sandler (2008), relies increasingly on alternate energy (para. 1). Another division of solar power is wind; developed "through 
highs and lows in temperature" (Alternate Energy Source, 2010, para. 1). National Geographic (2011) reports that "Industry experts predict . . . by 2050 the answer to one third of the world's electricity needs will be found blowing in the wind" (para. 8). These alternatives have substantially lower risks and use environmentally sustainable practices.

Creation of nuclear energy generates waste. Waste, for which there is no permanent solution. Professor Eric J. Hall posited that "life on earth has evolved amid the constant exposure to naturally occurring radiations from beyond earth [cosmic radiation] and from radioactive material within the earth's crust" (quoted in WNA, 2011, para. 1). This attitude leads some to believe permanent disposal for nuclear material presents no inconvenience. Nonetheless, nuclear waste is a growing problem that continues to plague countries like Canada. A primary source of nuclear waste is reactors. Nuclear SA (2002) lists other sources as the "mining and processing of uranium, nuclear weapons ... and nuclear power stations" (para. 2). The waste produced is radioactive for millennia.

"According to Environment Canada, true walk away disposal methods are unlikely to be possible given the long time periods . . . longer-lived radio nuclides would have to be isolated from the soil, air, and water" (Boyd, 2001, "Waste", para. 3). An article by Kemp (2009) reports that about two million used fuel bundles remain from Canada's forty-year history with nuclear creation ("Fuel Bundles Handled"). "After use in a nuclear power plant the bundles contain radioactive material . . . which can damage human tissue and cause cancer" (Kemp, 2009, "Enviro. Concern," para. 3). Considering the menacing potential of radiation on health, a community willing to host waste storage has yet to be found. With no permanent solution, nuclear waste concerns will never be resolved. "There are two million high-level radioactive fuel bundles sitting at temporary storage sites in Canada, as the Nuclear Waste Management Organization wrestles with the mandate of finding a community to host a central storage facility for the waste for perhaps tens of thousands of years" (Kemp, 2009, para. 1). An additional concern, which has amplified in recent years, is the potential for stored radioactive material to be accessed by terrorist activists.

Nuclear waste storage is one of several community concerns tied to nuclear energy. Nuclear plants such as the one proposed in Peace River, Alberta, put those communities at potential risk to befall the fate of people in Japan. Advocates, such as Tom Kauffman, senior media relations manager for the Nuclear Energy Institute in Washington, D.C, argue a Chernobyl-type disaster is not possible (Staedter, 2010, para. 7). While many nuclear reactors are now self-limiting, which Chernobyl's reactor was not; this does not guarantee a great discharge of radiological substance into the environment will not happen. 
All populations hosting nuclear plants are vulnerable to the devastation of a nuclear tragedy. All populations are defenceless against nature's wrath. All populations are susceptible to human and technological error. Alberta is not prone to violent earthquakes, nor to tsunamis; the cause of Japan's accident. Nevertheless, Alberta is susceptible to tornados. The families of people lost to the tornado on Black Friday, 1987, can attest to nature's destructive power.

Yet, nature is not the greatest vulnerability of nuclear power plants. Technological failure and human miscalculation pose far greater risks. Since 1952, thirty-three incidents have been identified at nuclear power plants (Rogers, para. 4). One such accident includes the Three Mile Island Nuclear Generating Station, in Pennsylvania, U.S. where according to WNA (2010), in 1976, the plant experienced a system failure, not immediately recognized by plant officials, that caused the reactor core to melt (para. 3). Although the incident at Three Mile Island is not rated as one of the most severe accidents, Helen Caldicott, an expert on radiation, notes that it took eleven years to clean up. The reactor building remains highly radioactive to date (p. 74). The International Chernobyl Radiation Portal acknowledges that, "on 26 April 1986, the most serious incident in the history of the nuclear industry occurred at Unit 4 of the Chernobyl nuclear power plant in the former Ukrainian Republic of the Soviet Union" ("Pfc: Chnbl Acdnt," para. 1). According to the IAEA the radiation levels released were 400 times that of the atomic bomb dropped on Hiroshima (para. 12). The 30 kilometre "exclusion zone" surrounding the plant, still effectively uninhabited (IAEA, para. 6), serves as a sobering reminder of the destructive power of nuclear energy when control slips out of human hands. As the reactor's concrete tomb begins to deteriorate, humans are not likely to forget any time soon.

Currently the Japanese public is struggling to return to normal life amid radiation concerns, report Alibaster and Yamaguchi (2011). Thousands are without power or running water, and 165,000 are living in shelters (para. 15). Nuclear power is a means to an end. Across the globe people have an obligation to weigh those means; disruption to the eco-system, accumulation of toxic waste, and radiation risk. They then have to decide what they are willing to lose to achieve that end. Before making that decision, it is important to consider that, in an instant, clean and efficient power could alter people's lives forever. 
* Author: Adriianne Foss is currently a first year student in the Bachelor of Applied Communications in Professional Writing program at Grant MacEwan University. She has a passion for environmental issues, and it is from this passion that she finds inspiration.

\section{References}

Alabaster, J. \& Yamaguchi M. (2011). Japanese prime minister visits tsunami-hit villages. The Globe and Mail. Retrieved (March 17, 2011), from http://m.theglobeandmail.com/news/world/asia-pacific/japanese-prime$\underline{\text { minister-visits-tsunami-hit-villages } / \text { article1967392/?service }=\text { mobile }}$

Alternate Energy Sources. (2011). 30 Facts about solar energy. Retrieved (March 17, 2011), from http://www.alternate-energy-sources.com/facts-about-solarenergy.html

Andseta, S., Thompson, M. J., Jarell, J. P., \& Pendergast, D. R. (1998). Candu Reactors and Greenhouse Gas Emissions. Retrieved (March 19, 2011), from: Computare Thinking About Climate Change http://www.computare.org/Support $\% 20$ documents/Publications/Life $\% 20 \mathrm{Cycl}$ e.htm

Blue Energy. (2009). Tidal Power. Retrieved (March 18, 2011), from http://www.bluenergy.com/TidalPower.htm

Boyd, D. R. (2001). Canada vs. the OECD: An environmental comparison. Retrieved (March 19, 2011), from http://environmentalindicators.com/htdocs/indicators/13nucl.htm

IAEA.(n.d.). Frequently asked Chernobyl questions. Retrieved (June 20, 2011), from http://www.iaea.org/newscenter/features/chernobyl-15/cherno-faq.shtml

Caldicott, H. (2006). Nuclear Power, Radiation, and Disease. Nuclear Power is not the Answer. New York: The New York Press. 
El-Hinnawi, E.E. (1976). Review of the environmental impact of nuclear energy. International Atomic Energy Agency Bulletin, 20(2), 32-42. Retrieved (March 18, 2011), from http://www.iaea.org/Publications/Magazines/Bulletin/Bull202/20205083242.p $\underline{\mathrm{df}}$

Hunt, T. \& Krieger, D. (2006). Does Nuclear Power Really Make Sense. Nuclear Age Peace Foundation. Retrieved (March 19, 2011), from http://www.wagingpeace.org/articles/2006/04/00 krieger hunt nuclearpower-sense.htm

Kemp, B. (2009). Storing nuclear waste a \$24-billion problem. CBC News Canada. Retrieved (March 17, 2011), from http://www.cbc.ca/news/canada/story/2009/08/18/f-nuclear-wastestorage.html

International Chernobyl Radiation Portal of the ICRIN project (2010). History of Chernobyl Disaster. Retrieved (June 19, 2011), from http://chernobyl.info/Default.aspx?tabid $=274$

National Geographic. (2011). Wind Power. Retrieved (June 19, 2011), from http://environment.nationalgeographic.com/environment/globalwarming/wind-power-profile/

NuclearSA. (2002). Nuclear W aste: Sources and Types. Retrieved (June 20, 2011), from http://www.ccsa.asn.au/nuclearsa/index.html

Paschoa, A.S., (2004). Environmental effects of nuclear power generation. Interactions: Energy/Environment. Encyclopaedia of Life Support Systems. [eolss.net] Retrieved (March 18, 2011), from http://www.eolss.net/ebooks/Sample\%20Chapters/C09/E4-23-03-03.pdf

Ramu. P. (2011). Radiation detected in Washington milk. CBC News Canada. Retrieved (June 19, 2011), from http://www.cbc.ca/news/canada/britishcolumbia/story/2011/03/30/bc-radiation-milk-washington-state.html

Rogers, S. (2011). Nuclear power plants: Listed and ranked since 1952. Guardian.co.uk. Retrieved (June 20, 2011) from http://www.guardian.co.uk/news/datablog/2011/mar/14/nuclear-power-plantaccidents-list-rank 
Sandler, N. (2008). At the zenith of solar energy. Bloomberg Business Week. Retrieved (March 19, 2011), from http://www.businessweek.com/globalbiz/content/mar2008/gb20080326 4855 $\underline{82 . h t m}$

Staedter, T. (2010). Is nuclear energy safe? Discovery News. Retrieved (March 17, 2011), from http://news.discovery.com/tech/is-nuclear-energy-safe.html

World Nuclear Association. (2011). Radiation and Life. Retrieved (March 19, 2011), from htt p://www.world-nuclear.org/education/ral.htm

World Nuclear Association. (2011). Nuclear Power in the World Today.

Retrieved (March 18, 2011), from http://www.world-nuclear.org/info/inf01.html

World Nuclear Association. (2011). Three mile island accident. Retrieved (June 19, 2011), from http://www.world-nuclear.org/info/inf36.html 